\title{
Mass flow analysis for anthropogenic micropollutants as performed in the Swist river catchment
}

\author{
A. F. Brunsch \\ Erftverband, Bergheim, Germany
}

\begin{abstract}
Monitoring activities for detecting micropollutant concentration ranges have been developed for the Swist river in the German state of North RhineWestphalia. The monitoring program covers various point and non-point emission input sources as well as immissions in the watercourse and takes regional factors such as climate, land use and population density into consideration. Data for a relatively large number (up to 160) and broad range of anthropogenic micropollutants (e.g. pharmaceuticals, pesticides and industrial chemicals) has been gathered and analysed. Substance loads at wastewater treatment plant outlets as well as within the river are calculated from flow data and substance concentrations. Sampling times are defined according to season and weather conditions. Knowledge has been gained regarding temporal and spatial variation in the appearance of micropollutants and the requirements for a monitoring program to cover these fluctuations. Moreover, experience has been gained in mass flow analysis and emission balancing.

Keywords: monitoring, emission, micropollutant, input dynamic, surface water.
\end{abstract}

\section{Introduction}

Studying the fate and behaviour of micropollutants has become a significant topic in water pollution research. Micropollutants have been detected in various parts of the water cycle including surface water, groundwater and drinking water. Despite the fact that they are found at very small concentration ranges measured in $\mu \mathrm{g} / \mathrm{L}$ or $n g / L$, many of them are of considerable toxicological concern, especially when present as components of complex mixtures [1]. Micropollutants can be assigned to the following substance groups: pharmaceutical compounds, 
pesticides, biocides, personal care products, disinfection products and industrial chemicals. Microbiological compounds such as germs are also micropollutants. Since the 1980s, when analytical methods to measure micropollutant concentrations became more precise, it has been possible to research these pollutants in more detail. Micropollutant inputs are now known to originate from wastewater treatment plant effluent, untreated sewer system overflow and landscape runoff. Various published studies list monitoring data from rivers and input sources, but input dynamics are likely to be neglected [2]. The European Water Framework Directive and the German Surface Water Ordinance require for various substances, including some micropollutants (pesticides and industrial chemicals), the reporting of only the annual average concentration in the river [3, 4]. But substance concentrations in river systems are variable. Fluctuation ranges should not be ignored, since high peak values in substance concentration can exert considerable pressure on the aquatic environment.

In order to gain useful knowledge of this fluctuation in substance concentration, a monitoring program for river systems has been established at the Swist catchment which ensures that the spatial variability and the variability over time in substance input and water quality can be sufficiently recorded.

\section{Planning mass flow analysis}

When setting up mass flow analysis for anthropogenic micropollutants it is necessary to identify sources and input pathways to the rivers. Thorough knowledge of the catchment is also required in terms of climate, hydrology habitation, industrial and agricultural activities. Additionally, the techniques deployed and the frequency of sampling should be adapted to catchment specific factors and expected fluctuation ranges.

\subsection{Micropollutant sources and input pathways}

Micropollutants have various emission sources and enter the watercourse through diverse pathways. To capture micropollution pressures on a system, input pathways from emission sources must be known. Such sources and pathways in both urban and rural areas are illustrated in Figure 1.

Micropollutant sources in the urban catchment include industry, households, building material containing biocides as additives and runoff from paved and unpaved ground. Pollutants from these sources enter the sewers, which are either combined sewers for carrying off rainwater together with sewage or separate sewer systems with separate piping networks for sewage and rainwater. Discharge from the combined sewer system and the sewage drain from the separate system enters the watercourse after passing through wastewater treatment plants. In case of rainfall or storm events there is additional pollutant input through separate sewer outlets and combined sewer overflows. The latter occurs only when the discharge exceeds the storage volume of the retention basin for the combined sewer. The following discussion introduces examples of micropollutant sources and their pathways to the watercourse. 


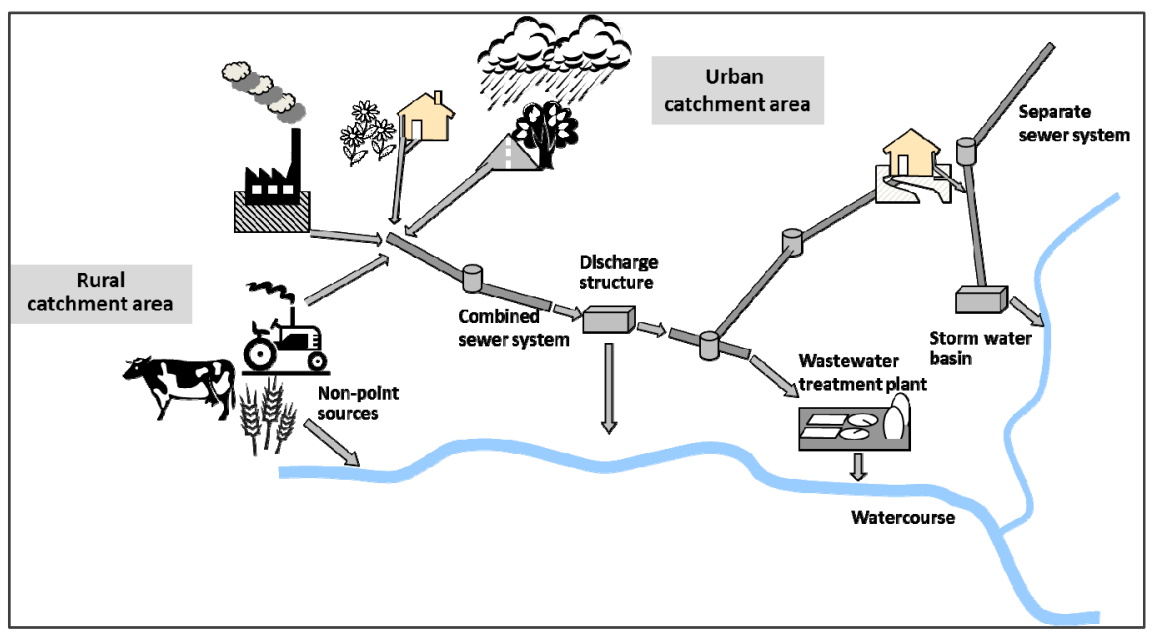

Figure 1: Source areas and inputs for anthropogenic micropollutants in watercourses (modified from Christoffels [5]).

Wastewater treatment plants are the main source of discharge of pharmaceutical compounds into watercourses [6]. A portion of drugs leaves the human body unmetabolized and enters the sewer system as pharmaceutical residues. Depending on their chemical characteristics, numerous pharmaceuticals are not well eliminated in wastewater treatment plants [7] and are hence discharged into the rivers. This is also true for a large number of personal care products and industrial chemicals. Population density and settlement patterns as well as local industry and medical facilities in the catchment are thus relevant as regional factors.

In the urban setting, biocides are used for garden maintenance in parks and public or private gardens. They are also used as an additive in building materials to prevent microbial growth. During rain events these biocides are washed out from building fronts [8].

Pollution stemming from the rural part of a catchment first depends on land use, with agricultural activity the primary source. Micropollutant pathways can firstly be straight from fields to watercourses. Type and intensity of farming are determining factors, as micropollutant runoff from a cultivated field, for example, is influenced by amount and type of chemicals deployed to protect a specific crop. Local conditions of farming practice (time of applications and equipment utilised), soil type and weather also influence micropollutant concentration in runoff. Furthermore, veterinary drug residues in animal waste spread as dung for field crops can reach the rivers through surface or subsurface runoff after rain events.

Pesticide and herbicide pathways can secondly be through the sewer system due to incorrect cleaning of plant sprayers and tractors in the farmyard. This also occurs through dumping of leftover pesticides into the sewer canal [9]. 


\subsection{Climatic and hydrological factors}

Climatic and hydrological factors are the driving variables impacting transport and delivery of substances and thus strongly influence emissions, water quality and ecological status. Regional climate conditions are characterised in terms of the amount of precipitation and frequency of flood events in a catchment area. During flood events, separate sewer outlets and combined sewer overflows discharge into the rivers. In addition, landscape runoff, including surface runoff and subsurface flow, both of which can contain pesticide residues, reaches the rivers. However, during dry weather conditions the proportion of wastewater treatment plant discharge in the river is high compared to wet weather. This is especially true for small rivers and creeks, where the amount of wastewater discharge can overshadow water from natural sources.

\subsection{Planning a monitoring strategy}

With knowledge of the specific catchment, decisions can be made regarding techniques deployed as well as the spatial and temporal extent of the monitoring program. Choosing the right locations and methods of sampling is essential for establishing a complete mass flow analysis, given the diverse source areas and input pathways as presented above (see also Figure 1). As noted, the amounts of substance input are not constant but fluctuate, according to the compound and the source.

Grab sampling and automatic sampling are two primary methods employed to achieve full monitoring coverage of short and long term developments as well as immediate events. Advantages of grab sampling are that the location of sampling is flexible and the point in time of sampling is freely selectable. One disadvantage is the time-consuming labour requirement. The main advantage of the automatic sampling systems is that samples can be taken in high temporal resolution as programmed by the user. If weather specific sampling is intended, the autosampler can be programmed to take samples without a time delay. One disadvantage is that the sampling location is static. With both grab sampling and automatic sampling it is not possible to monitor substance input over a whole time episode without time gaps. To perform sampling with no time gaps passive samplers are the most suitable, as they collect any substances which occur over a defined period of time.

Planning a monitoring strategy also entails consideration of time scale. In general, substance monitoring can be carried out on different time scales, short or long, depending on the data requirement. Moreover, sampling frequency should be adapted to the typical dynamics of the system [10] as manifested in precipitation patterns, seasonal or diurnal variations etc. Given the diversity of micropollutant substance groups and single compounds, a further consideration arises from their diverse temporal dynamics based on their chemical properties and how they interact with the aquatic environment over shorter and longer periods of time. Input dynamics, correspondent to the various input pathways, are also a factor in planning a program of monitoring. 
The driving variables and therefore the aquatic system can change on a wide range of time scales, from hours and days to years and decades. Driving variables which can exert a short time influence on the watercourse and water quality include rainfall and storm events, disease outbreaks associated with high usage of pharmaceuticals and incorrect disposal of harmful substances (e.g. industrial chemicals, pesticides, drugs) such that they can enter the sewer network. Variables which have long time effects on emission inputs and/or the water quality include: legal prohibition of harmful substances, new products and changes in consumer behaviour, changes in land use, climate and demographic change as well as improved wastewater treatment techniques.

\section{Characteristics of the research catchment}

An integrated approach to monitoring based on the factors described in Section 2 has been applied to a watercourse called the Swist, a tributary of the Erft river in the greater Rhine catchment. The Swist is a stream with a total length of 43.6 kilometres. The catchment area covers $289 \mathrm{sq}$. km. The average precipitation height (Weilerswist gauge 1972-2001) is $659 \mathrm{~mm} / \mathrm{a}$ [11]. The largest part of the catchment lies in the rain shadow of the Eifel mountain range, which means that there is less precipitation than in adjacent regions. In the northern part of the Erft catchment, for example, about $750 \mathrm{~mm}$ average precipitation per year was measured [12].

The Swist has an average water flow at the mouth of $815 \mathrm{~L} / \mathrm{s}$ (Weilerswist gauge 1970-2011). However, the water level of the Swist is highly variable. In longer periods without rainfall many tributaries of the Swist dry out and the wastewater load in the Swist - coming from four small to middle sized wastewater treatment plants - is more than $50 \%$ of the overall water flow.

A total of nearly $30 \%$ of the catchment is forested. The climatic situation and fertile loess soils in the catchment allow intensive agricultural use $(44 \%$ arable land). Widespread arable fields are cultivated with wheat and sugar beet. Orchards are also characteristic in the catchment area. About $95 \%$ of farmland is located at a distance of less than 500 meters from the waters; $10 \%$ are less than 50 meters from the waters.

\section{Swist monitoring program in practice}

The Swist monitoring program is designed to detect micropollutant inputs from all significant emission pathways under a variety of scenarios. Typical water quality parameters are included in the program as well. Data analysis is performed to identify fluctuation ranges and worst case scenarios. A summary of the monitoring methods deployed in the Swist catchment area is presented in Table 1. Techniques applied and time scales of sampling as introduced above are noted. 
Table 1: $\quad$ Summary of sampling systems deployed along the Swist; CSO = combined sewer overflow, $\mathrm{SSO}=$ separate sewer outlet, WWTP = wastewater treatment plant (modified from Brunsch and Christoffels [13]).

\begin{tabular}{|c|c|c|c|c|}
\hline & WWTP & CSO and SSO & $\begin{array}{l}\text { Landscape } \\
\text { runoff }\end{array}$ & Watercourse \\
\hline $\begin{array}{l}\text { Monitoring } \\
\text { technique }\end{array}$ & Grab sampling & $\begin{array}{l}\text { Automatic } \\
\text { sampling }\end{array}$ & $\begin{array}{l}\text { Passive sampling } \\
\text { - collecting } \\
\text { surface and } \\
\text { subsurface runoff }\end{array}$ & $\begin{array}{l}\text { Grab sampling; } \\
\text { automatic } \\
\text { sampling }\end{array}$ \\
\hline $\begin{array}{l}\text { Type of } \\
\text { coverage }\end{array}$ & Event based & $\begin{array}{l}\text { Event specific; } \\
\text { with respect to } \\
\text { storm water }\end{array}$ & $\begin{array}{l}\text { Episode specific; } \\
\text { long-term }\end{array}$ & $\begin{array}{l}\text { Event based; } \\
\text { regular }\end{array}$ \\
\hline $\begin{array}{l}\text { Sampling } \\
\text { location }\end{array}$ & $\begin{array}{l}\text { Drainage shafts at } \\
\text { the outlet; canals } \\
\text { at the inflow }\end{array}$ & $\begin{array}{l}\text { Private property } \\
\text { to avoid } \\
\text { tampering with } \\
\text { the sampling } \\
\text { device }\end{array}$ & $\begin{array}{l}\text { Farm land, } \\
\text { riparian strips; } \\
\text { rectangular box } \\
\text { embedded in the } \\
\text { soil right along } \\
\text { the watercourse; } \\
\text { Consent of land } \\
\text { owner required }\end{array}$ & $\begin{array}{l}\text { Sampling at } \\
\text { various points } \\
\text { along the } \\
\text { watercourse: } \\
\text { bridges are } \\
\text { advantageous }\end{array}$ \\
\hline $\begin{array}{l}\text { Additional } \\
\text { parameters }\end{array}$ & $\begin{array}{l}\text { Meteorological } \\
\text { and hydrological } \\
\text { data for event } \\
\text { based sampling; } \\
\text { hydraulic data for } \\
\text { load calculation }\end{array}$ & $\begin{array}{l}\text { Meteorological } \\
\text { and hydrological } \\
\text { data; discharge } \\
\text { data from sewer } \\
\text { system }\end{array}$ & $\begin{array}{l}\text { Meteorological } \\
\text { and hydrological } \\
\text { data }\end{array}$ & $\begin{array}{l}\text { Meteorological } \\
\text { and hydrological } \\
\text { data for event } \\
\text { based sampling; } \\
\text { hydraulic data } \\
\text { for load } \\
\text { calculation }\end{array}$ \\
\hline $\begin{array}{l}\text { Length of } \\
\text { monitoring }\end{array}$ & $\begin{array}{l}\text { Based on weather } \\
\text { conditions and } \\
\text { seasonal factors }\end{array}$ & $\begin{array}{l}\text { Optional; at } \\
\text { varying intervals }\end{array}$ & $\begin{array}{l}\text { Continuous with } \\
\text { respect to rain } \\
\text { events; } \\
\text { Regeneration of } \\
\text { the soil after } \\
\text { installation: } 1-2 \\
\text { years }\end{array}$ & $\begin{array}{l}\text { 1) Based on } \\
\text { weather } \\
\text { conditions and } \\
\text { seasonal factors } \\
\text { 2) Long-term, } \\
\text { routine } \\
\text { monitoring } \\
\text { 3) Special } \\
\text { campaigns }\end{array}$ \\
\hline
\end{tabular}

Since a substantial amount of pharmaceutical emissions have their source in domestic wastewater, all four wastewater treatment plant outlets in the Swist catchment area have been tested: Two larger plants with flocculation filtration downstream of an activated sludge process; and two smaller plants in more rural locations with trickling filter systems downstream of activated sludge processes. In a special one-day monitoring campaign inflow at all four plants has been analysed along with outflow at one-hour intervals to assess cleaning capacities of the plants and to identify fluctuations in pollution inputs coming from the sewer system. The technique used for sampling wastewater treatment plants is grab sampling, which is specifically addressed to scenarios such as severe weather conditions, disease outbreaks or times of pesticide application.

To determine emissions from event specific inputs, such as storm water events, water samples from one combined sewer overflow (including a retention soil filter) and one storm water basin which is an outlet of a separate sewer 
system have been chosen for study as representative examples of the 52 Swist sewer system discharge sites. At the combined sewer overflow, first flush effects on substance concentrations were considered. For sampling this event specific discharge in high time resolution, programmable automatic sampling systems are used.

Non-point sources are also considered. The main input of micropollutants such as pesticides takes place on non-point pathways and is episodic. In order to sample this runoff from landscape, a specially developed monitoring device which is actually dug into the soil is deployed at nine different sites representing the four predominant types of land use (crop land, forest, orchard, pasture). With these systems it is possible to sample both surface runoff and subsurface runoff [14].

Six grab sampling sites along the Swist have been selected for testing immissions in the watercourse. Two lie in the upper reach, with no influence from wastewater treatment plants, but with influence from sewer system outlets and landscape runoff. The other four sites in the middle and lower course are affected in addition by wastewater treatment plant discharges. Monitoring for micropollutants in the Swist watercourse itself is first of all event based, as with the measuring of wastewater treatment plant outflows. In addition, long-term, routine monitoring is also performed three times a year near the mouth.

An automatic sampling system combined with an online monitoring station is also located close to the mouth. There, the most important water quality parameters can be tested continuously in intervals from 10 seconds to 10 minutes. If any of the analysed parameters does not satisfy certain quality limits, the samples are kept for detailed laboratory analyses, for micropollutants among other parameters. This automatic sampling system was utilised in a special oneday campaign conducted to assess diurnal fluctuation in 130 different micropollutants near the mouth.

The results provide knowledge about the current water quality situation, identify the most important input pathways and detect long-term and short-term variation in micropollutant concentration in the river.

\section{Selected monitoring results}

The Swist monitoring program is composed of a series of discrete monitoring campaigns carried out over various timeframes. Since there are various different and still ongoing campaigns as discussed above, a choice of results is presented in the following. The focus will be on temporally varying pollution inputs.

The amount of analysed micropollutants alternated with the monitoring campaign. From 2009 to 2013 an average number of 36 pharmaceuticals and personal care products and 65 pesticides and transformation products of pesticides were tested in 8 special campaigns. The relative frequencies of positive findings in the Swist for these campaigns are shown in Figure 2. The significant influence of wastewater treatment plant discharge can clearly be seen in the longitudinal profile. This is especially true for pharmaceuticals and personal care products. Pesticides again enter the watercourse not only through 


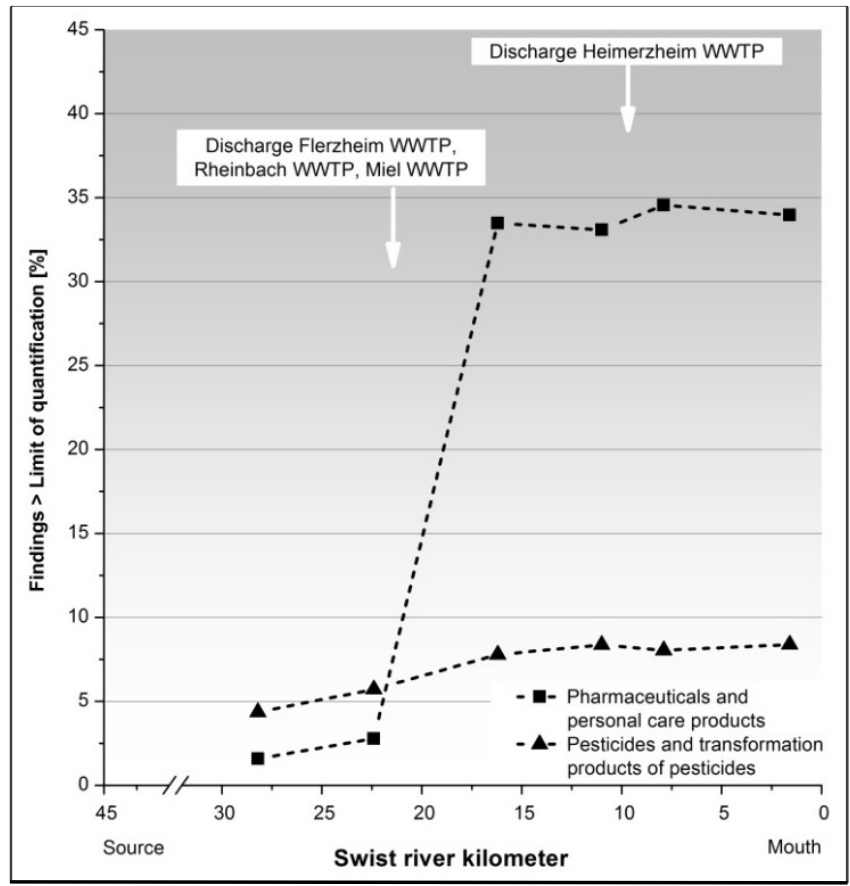

Figure 2: Presence of micropollutants in the Swist (longitudinal profile); relative frequency of findings > limit of quantification; September 2011 until June 2013. Sampling method: Grab sampling.

wastewater treatment plants but also through other input pathways such as landscape runoff.

Seasonal variations in substance input occur for some pollutants, mainly pesticides, but also for some pharmaceuticals such as antibiotics. Monitoring results show that pesticide input from landscape runoff is higher in spring and summer than in autumn and winter. By contrast, concentrations of some tested pharmaceuticals (antiphlogistics, antibiotics) are higher in winter than in summer. Possible reasons for these results could be increased usage in winter or slower degradation in winter.

Concentrations of some substances are found to vary appreciably depending on the day of the week on which sampling is performed. X-ray contrast media display the greatest such variation of the tested substances in the wastewater treatment plants and the Swist. The concentrations of Iomeprol, for example, were on Mondays noticeably lower compared to those on Wednesdays or Thursdays. The median concentrations at the outlet of four wastewater treatment plants on two Mondays were $0.19 \mu \mathrm{g} / \mathrm{L}$. However, the median concentration for two Wednesdays and three Thursdays was $0.99 \mu \mathrm{g} / \mathrm{L}$. Such great differences have not been detected for other substance groups. This has to do with the fact that the use of x-ray contrast media is limited to x-ray practices and hospitals. 


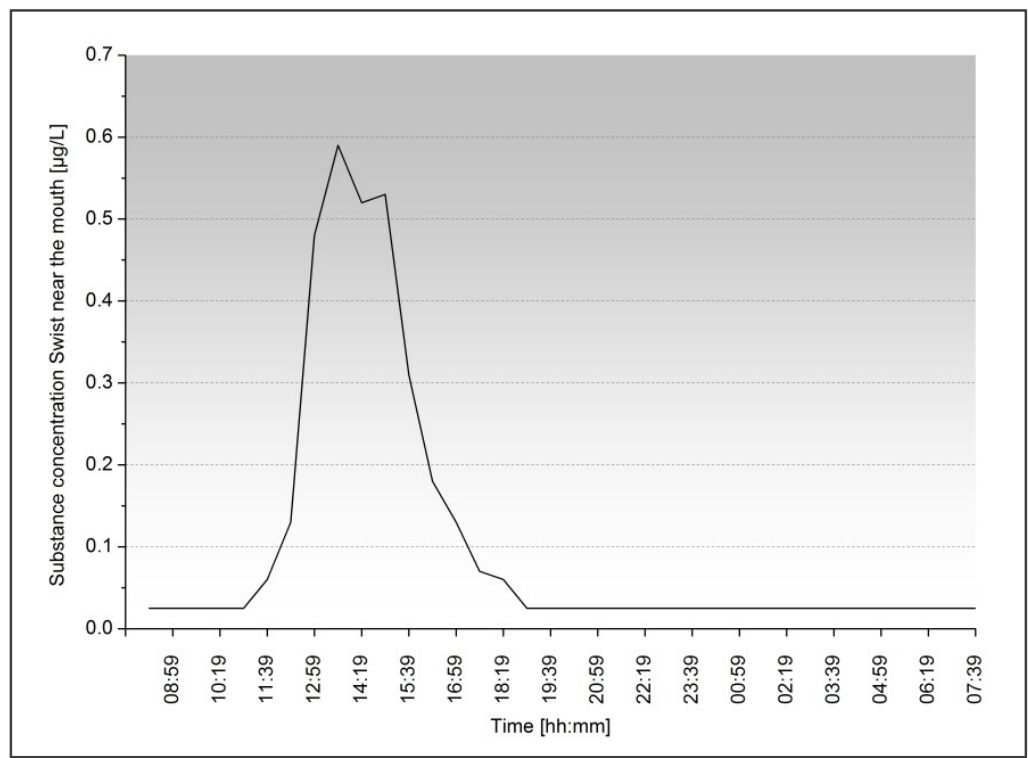

Figure 3: Substance concentration for pesticide Haloxyfop in the Swist near the mouth on 08/09.10.2013; sampling method: automatic sampling, 24 hour sampling campaign, 40 minute composite samples.

These medical examinations take place mostly during weekdays from Monday to Friday [13].

As mentioned in the previous section, to investigate diurnal fluctuations in micropollutants, a 24-hour sampling campaign was undertaken for 130 substances. Figure 3 shows results for detection of one of them, the herbicide Haloxyfop. Samples were taken from the Swist river close to the mouth. The influence of this discontinuous pollutant input can clearly be seen on the chart.

Grab sampling is also regularly performed and was first done for micropollutants in the 1990s. With these results long term changes or trends in substance concentrations can be identified. Figure 4 shows measured concentrations of the three pesticides Simazin, Diuron and Isoproturon, of which Simazin and Diuron were banned in 2000 and 2007 respectively (Diuron with some exception permitting usage as biocide). Simazin and Diuron concentrations clearly decreased after their prohibition. Isoproturon, which is still authorised for agricultural use, is also measured in the watercourse.

The techniques applied, with attention to input pathways, thus yield information on micropollutant fluctuations in various timeframes. 


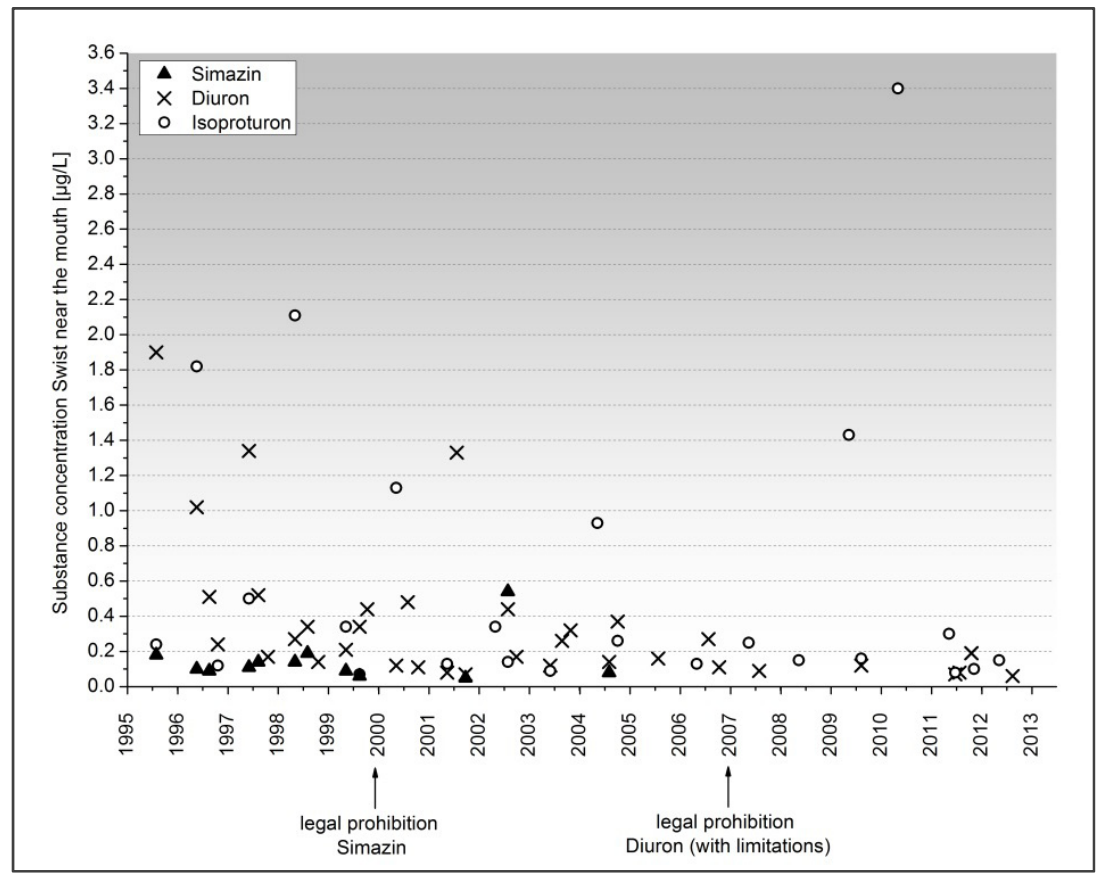

Figure 4: Pesticide concentration for Simazin, Diuron and Isoproturon measured in the Swist near the mouth for the years 1995-2012; sampling method: grab sampling.

\section{Summary and future perspectives}

The emission inventory to determine micropollutant input as implemented in the Swist river basin is conducted with monitoring points situated on the most important emission pathways (wastewater treatment plant, combined sewer overflow, separate sewer outlet, non-point input). Immission monitoring subsequently helps determine cause-effect relationships between emissions and water quality in rivers. It is thus anticipated that the monitoring program implemented on the Swist river will prove its worth by providing a clear view of the water quality situation in the watercourse and sources of pollution in the catchment.

The acquired monitoring data serve as a basis for precise load calculations. Event specific monitoring at the most important emission outlets and in the river serves to distinguish base scenarios from worst case scenarios. Pressures on the aquatic ecosystem can then be shown in detail. Furthermore, it is possible to identify temporal pollution peaks which can have, depending on the pollutant, enormous effects on the aquatic environment. 
The knowledge acquired through the monitoring program will facilitate the selection of targeted measures to reduce micropollutant input in surface waters.

\section{Acknowledgements}

Development and deployment of the monitoring systems presented in this paper has been funded in the framework of following projects:

- $\mathrm{M}^{3}$ “Application of integrated modeling and monitoring approaches for river basin management evaluation", funded by the European Union initiative Life+

- TAPES "Transnational Action Program on Emerging Substances" funded through the Interreg IVb NWE programme

- "Evaluation of measures to reduce physical, chemical and microbiological loads in rivers with the example of the Swist river" funded through the Ministry for Climate Protection, Environment, Agriculture, Conservation and Consumer Protection of NRW

The author is grateful for the financial support of the project. Thanks also to the colleagues from the Erftverband: E. Christoffels, F.-M. Mertens, J. Wunderlich-Pfeiffer, R. Krump, O. Altunay, M. Trimborn, S. KindgenGronwald, M. Reif, the staff at the wastewater treatment plants and B. Smallberg.

\section{References}

[1] Schwarzenbach, R.P., Escher, B.I., Fenner, K., Hofstetter, T.B., Johnson, C.A., von Gunten, U. \& Wehrli, B., The challenge of micropollutants in aquatic systems. Science, 313, pp. 1072-1077, 2006.

[2] Bergmann, A., Fohrmann, R. \& Weber, F.-A., Zusammenstellung von Monitoringdaten zu Umweltkonzentrationen von Arzneimitteln. Umweltbundesamt (ed.), Dessau-Roßlau, 2011.

[3] European Commission. Directive 2008/105/EC of the European Parliament and of the Council of 16 December 2008 on environmental quality standards in the field of water policy, amending and subsequently repealing Council Directive 82/176/EEC, 83/513/EEC, 84/156/EEC, 84/491/EEC, 86/280/EEC and amending Directive 2000/60/EC of the European Parliament and of the Council. Office Journal L 348/84, 2008.

[4] OGewV. Oberflächengewässerverordnung vom 20. Juli 2011 (BGBl. I S. 1429), 2011.

[5] Christoffels, E., Erftverband, unpublished, 2012.

[6] Ternes, T.A., Occurrence of drugs in German sewage treatment plants and rivers. Water Research, 32 (11), pp. 3245-3260, 1998.

[7] Carballa, M., Omil, F., Lema, J.M., Llompart, M., García-Jares, C., Rodríguez, I., Gómez, M. \& Ternes, T., Behavior of pharmaceuticals, cosmetics and hormones in a sewage treatment plant. Water Research, 38, pp. 2918-2926, 2004.

[8] Burkhardt, M., Junghans, M., Zuleeg, S., Schoknecht, U., Lamani, X., Bester, K., Vonbank, R., Simmler, H. \& Boller., M., Biozide in 
Gebäudefassaden - ökotoxikologische Effekte, Auswaschung und Belastungsabschätzung für Gewässer. Umweltwissenschaften und Schadstoff-Forschung, 21, pp. 36-47, 2009.

[9] Blarr, A.S., Erkennung, Quantifizierung und Verminderung punktueller Pflanzenschutzmittel-Einträge in Oberflächengewässer. Dissertation at Justus-Liebig-Universität Gießen, 2008.

[10] Wilkinson, J., Souter, N. \& Fairweather, P., Best practice framework for the monitoring and evaluation of water-dependent-ecosystems 1: Framework. Government of South Australia, through Department of Water, Land and Biodiversity Conservation (ed.), Adelaide, 2007.

[11] Kistemann T., Koch C., Classen T., Rechenburg A., Kramer F., Herbst S., Franke C., Rind E., Höser C., Exner M., Christoffels E., Krump R., Willkomm M, Thormann D., Hiller A. \& Lindner W., Mikrobielle Fließgewässerbelastungen durch abwassertechnische Anlagen und diffuse Einträge. Ministerium für Umwelt, Naturschutz, Landwirtschaft und Verbraucherschutz NRW (ed), Online http://www.umwelt.nrw.de/umwelt /pdf/mikro.pdf, 2009.

[12] Erftverband (ed), Jahresbericht 2011, Bergheim, 2011.

[13] Brunsch, A. \& Christoffels, E., Monitoring guideline - Monitoring system for surface and subsurface runoff, Automatic sampling devices, Xenobiotic monitoring campaign (Chapter 2.6, 2.8, 2.11). Application of integrative modelling and monitoring approaches for river basin management evaluation - The Book, pp. 92-138, online http://www.lifem3.eu/fileadmin/M3-life/downloads/Book.pdf, 2013.

[14] Christoffels, E. Chemisch-physikalische Stoffeinträge in die Fließgewässer aus den Abflusskomponenten des Landschaftswasserhaushalts Teil 2: Technik, Ergebnisse und Plausibilitätsuntersuchungen. Korrespondenz Wasserwirtschaft, 10 (4), pp. 548-552, 2011. 